\title{
Dangers of industrial domination of academic research
}

\section{London}

Government science policies which encourage 'industrialization' of academic research and aim at national leadership in science and technology may be seriously flawed, according to this year's annual report of the Organisation for Economic Cooperation and Development (OECD) on science and technology policy. In many countries, industry is substantially expanding its research activity and governments are pressing academic institutions to form closer links with industry. The result is increasing commercialization of scientific knowledge and a system of research that is more practical, short-term and commercial in its orientation. But the report says both academics and industrialists are concerned about how far this should go. "Traditional research systems, with universities at their core, have served the broad public interest very well in many countries. Radical change which compromises the primary function of academic institutions - education and basic research - may not serve these interests."

Business enterprises now account for a substantial, and the most rapidly growing, part of total national expenditures on $R \& D$, says the report. In Japan and the United States in particular, industry has become a major supporter of basic research. In Japan, almost 35 new laboratories have been opened in the last 3-4 years.

But the report disagrees with governments which believe that by encouraging industry to support research in academic institutions, public expenditure on research could be reduced. Although industrial investment is increasing, it is still relatively small, is directed to only a narrow segment of research fields, and is focused on short-term returns on investments. And because of the 'explosive' growth of opportunities for important basic research only a fraction of which is being funded, there is little scope for reducing the overall amount of research support to universities as a result of rising industrial funding.

The OECD is also concerned that the growing 'industrialization' of research is threatening the accessibility of research results. "The prompt and open publication of basic scientific research has worked well and the practice should not be discarded lightly", it says. But the trend towards increasing confidentiality of results has already begun. Decisions concerning publication often rest with the industrial sponsors of academic research and institutions sometimes agree to delay publication for a year, to allow the company to apply for patents. Changes in intellectual property rules would ensure results were protected as well as being accessible, says the report.

The OECD also criticizes government policies on international collaboration as being out of touch with changes taking place within both universities and industry. Academic institutions are cooperating more with foreign institutions and companies, as are industrial firms. But government policies do not reflect this trend, and are based on the belief that the national 20

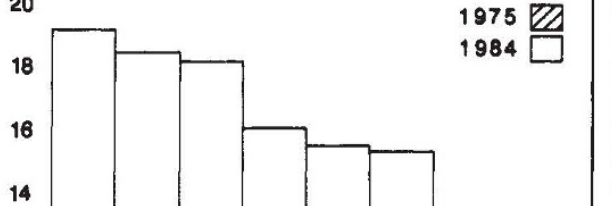

German maglev trains way ahead of rivals

\section{Hamburg}

JAPAN may have captured the publicity and the world speed records - for magnetically levitated trains, but West Germans believe they will win the race for successful commercial operation. Magnetically levitated trains have been running on a $31.5 \mathrm{~km}$ test track in Lower Saxony since 1983 and the federal government has now decided to build the world's first inter-city track for commercial traffic. It will link Hanover and Hamburg, and trains will cover the 155 kilometres in just $30-40$ minutes.

The builders, a consortium including Thyssen Henschel, MesserschmidtBölkow-Blohm and Krauss-Maffei, want to demonstrate the feasibility of the new trains under real conditions. They claim to be five years ahead of the Japanese companies who are their only competitors.

The German "Transrapid" train uses conventional magnets, rather than the superconducting magnets favoured by the Japanese. Wing-like traps fold under a central $\mathrm{T}$-shaped guideway beneath the train to pull the car a centimetre into the air by magnetic attraction. The Japanese train, in contrast, sits in a U-shaped guideway lined with aluminium coils. Magnetic repulsion pushes the car ten centimetres off the ground.

The track between Hamburg and Hanover will cost DM 1,800 million ( $\$ 1,000$ million) and will be ready by the mid-1990s. But long before then, industry hopes to win orders from abroad. Under consideration are maglev routes between Moscow and Leningrad in the Soviet Union, Mecca and Medina in Saudi Arabia, and Ottawa and Montreal in Canada. A definite possibility is a link between Los Angeles and Las Vegas, which would cut the travel time from five hours by car to 70 minutes by train.

But not all West German companies are happy about the train. The Transrapid TR-07, now under construction, will reach $500 \mathrm{~km}$ per hour, and could so improve on air travel times within Germany as to take business away from Lufthansa.

The federal railway company Deutsche Bundesbahn is also worried by the train. The company runs at an enormous loss its total debt is close to DM 45,000 million ( $\$ 24,000$ million) - and has spent huge sums on a new rapid train called Inter-City Experimental. A superfast competitor could render these rapid trains obsolete; in hilly country maglev track costs about DM 30 million per kilometre against InterCity Experimental's DM 40 million.

Jürgen Neffe technologies elsewhere.

Christine McGourty 